\title{
ОПЫТ ДИАГНОСТИКИ И ЛЕЧЕНИЯ АРТЕРИОВЕНОЗНОЙ МАЛЬФОРМАЦИИ СОСУДОВ МАЛОГО ТАЗА У ДЕВОЧКИ ШЕСТИ МЕСЯЦЕВ
}

\begin{abstract}
И.В. ГАВРИЛОВА
заведующая отделением детской и подростковой гинекологии Национальной детской специализированной больницы «Охматдет»
\end{abstract}

\section{Т.Ф. ТАТАРЧУК}

д.мед.н., просрессор, член-кор. НАМН Украины, заместитель директора по научной работе, заведующая отделением эндокринной гинекологии Института педиатрии, акушерства и гинекологии НАМН Украины

\section{И.В. БАЧИНСКАЯ}

детский гинеколог отделения детской и подростковой гинекологии Национальной детской специализированной больницы «Охматдет»

\section{И.В. АЛЬТМАН}

научный сотрудник отдела рентгенэндоваскулярной хирургии и ангиографии Национального института хирургии и трансплантологии им. А.А.Шалимова НАМН Украины

\section{Ю.Л. КУЗЬМЕНКО}

заведующая отделением рентгентерапии и эндоваскулярной хирургии ГУ «Научнопрактический медицинский центр детской кардиологии и кардиохирургии МЗ Украины»
A ртериовенозные мальформации (АВМ), или ангиодисплазии могут располагаться в различных органах, на конечностях, голове и шее, в органах малого таза. АВМ матки - непосредственная коммуникация маточных вен с ветвями артерий разного калибра из бассейнов внутренних подвздошных артерий. Существует два типа АВМ матки: врожденные мальфрормации и приобретенные (трофобластическая болезнь, аденомиоз и др.). Синонимы АВМ матки: дифрфузный кавернозный ангиоматоз, ангиодисплазия матки, артериовенозные соустья или шунты, лагуны, варикозная аневризма матки [9].

ABM матки - очень редкая патология. За девяносто лет наблюдений в мировой литературе представлено менее 150 случаев истинных АВМ матки, в основном у взрослых; первое клиническое наблюдение относится к 1926 г. У детей описаны единичные случаи - у мертворожденной девочки [7] и у девочки 10 лет [1].

Для врожденных АBM характерна дисплазия сосудов: отсутствие всех типичных слоев и обилие в стенках глиальных и коллагеновых волокон, аномальная пролиферация. Эти изменения являются наследственным дефектом. По данным литературы, дисплазии относятся к высокодифференцированным сосудистым образованиям и не малигнизируются [2].

В экспериментальных работах доказана полная идентичность френотипических и ангиогенных свойств эндотелиальных клеток сосудов при АВМ и васкулярных клеток вен, артерий, капилляров пуповины. Вместе с тем установлено ряд отличий: превышающая в 1,8-6,4 раза частота их спонтанной пролифрерации; отсутствие чувствительности к ингибирующему влиянию большинства цитокинов, включая интерлейкин- $\beta$, фрактор некроза опухоли-а, трансформирующий фактора роста- $\beta$ и интерферон- $\gamma$; а также резистентность к апоптозстимулирующему влиянию дексаметазона и трансформирующего фрактора роста- $\beta$.

На основании полученных результатов сделано заключение о том, что аномальная пролиферация артериовенозных дисплазий происходит в результате наследственного дефекта процессов запрограмированной гибели клеток [13].

Клиника заболевания характеризуется кровотечениями из половых путей (как из матки, так и из влагалища) - менструальными и межменструальными, при беременности, в родах.
Отличительная особенность этих кровотечений - отсутствие эффректа от традиционных консервативных методов лечения. В ряде случав возникают тяжелые постгеморрагические осложнения, требующие реанимационных мероприятий.

Наиболее доступный метод диагностики сосудистых аномалий развития женских гениталий УЗИ. При исследовании в В-режиме определяется множество четко отграниченных анэхогенных включений всевозможных форм и диаметра, занимающих большую часть миометрия [1, 2]. При использовании цветного допплеровского картирования (ЦДК) оценивают скорость, направление, тип кровотока. Для АВМ характерен высокоскоростной турбулентный кровоток, что отличает их от гемангиом, для которых свойственны низкая скорость и венозный тип кровотока.

Более точное представление о локализации ABM и ее ангиоархитектонике дают данные МРТ и МР-ангиографиии.

Золотым стандартом диагностики АВМ считается ангиография, позволяющая визуализировать сосудистое образование, определить основной питающий сосуд [3].

С.А. Леваков и соавт. (2010) обобщили мировой опыт лечения АВМ матки (табл). Эмболизация маточных артерий (ЭМА) является наиболее эффрективным методом [4, 5]. Аналоги гонодотропин-рилизинг гормона (ГнРГ) применяли в основном при подготовке к ангиографии [10-12]. Экстирпацию матки (ЭМ) проводили при неэфффективности терапии [6, 8, 9, 14]. В ряде случаев после эффрективного лечения наступала беременность [11].

Селективная эмболизация артерий желудка при массивном желудочном кровотечении впервые успешно применена в 1972 г. Метод нашел широкое применение при остановке различных кровотечений, в частности акушерских; в гинекологии для лечения фрибромиом матки с сохранением репродуктивной фрункции, при различных локализациях АВМ.

При АВМ матки и органов малого таза селективная эмболизация ветвей внутренней подвздошной артерии - наиболее оптимальный метод лечения, позволяющий сохранить репродуктивную функцию. По данным литературы, эфффективность лечения составляет 64-93\%.

ЭМА - метод минимально инвазивной терапии - сегодня активно развивается. Разра- 
ботан целый ряд эмболизирующих веществ, широко используется поливинилалкоголь. В литературе описано применение желатиновых частиц, гидрогеля - цилиндрических и сорерических отливок из полигидрооксиэтилметокрилата, смеси контрастного жирорастворимого вещества и антибиотиков [2, 3].

Сообщений о лечении АВМ матки у детей младшего возраста не обнаружено, что обусловило необходимость опубликовать наше клиническое наблюдение.

М-ва Карина, 2010 г. рождения (6 мес) 23 июня 2011 г. поступила в отделение детской и подростковой гинекологии Национальной детской специализированной больницы «Охматдет» по направлению Одесской областной детской клинической больницы с диагнозом «маточное кровотечение». Анамнез заболевания: скудные кровяные выделения на третьи сутки после рождения расценены как половой криз. В четырехмесячном возрасте возникло обильное кровотечение из половых путей. Девочку госпитализировали в реанимационное отделение по месту жительства. Ей была проведена гемотрансфузия, диагностическая лапаротомия (по утверждению оперировавшего хирурга патологических образований в малом тазу не выявлено) и установлен диагноз преждевременного менархе (транзиторная фрорма).

В июне 2011 г. произошло повторное массивное кровотечение, больную госпитализировали в отделение реанимации детской больницы Одессы, провели гемотрансфузию. После стабилизации состояния ее направили в «Охматдет».

При обследовании в больнице «Охматдет» установлено, что уровень половых и гонадотропных гормонов в крови соответствует возрасту.

23.06.2011 г. выполнено УЗИ органов малого таза: тело матки 28/15×16×18 мм, М-эхо 1 мм, по передней стенке в области перешейка имеется опухолевидное образование гетерогенной структуры без четких контуров - 32×23×30 мм. В режиме ЦДК участок интенсивно васкуляризирован, характер кровотока смешан с шунтами, высокоскоростной. Яичники: правый 16×6 мм, левый $13 \times 7,5$ мм. Скорость кровотока $-95,5$ см/сек ИР - 0,274 (рис. 1).

С целью диффференциальной диагностики характера образования произведено МРТ малого таза с внутривенным контрастированием в Национальном центре детской кардиологии и кардиохирургии. Заключение центра: сосудистое образование малого таза по данным МРТ соответствует АВМ.

Согласно МРТ до лечения, на рисунках 2 А и 2 Б отчетливо видно, что сосудистое образование занимает не только матку, но и распространяется в область параметриев, почти достигая стенок таза; определяются питающие образование сосуды.

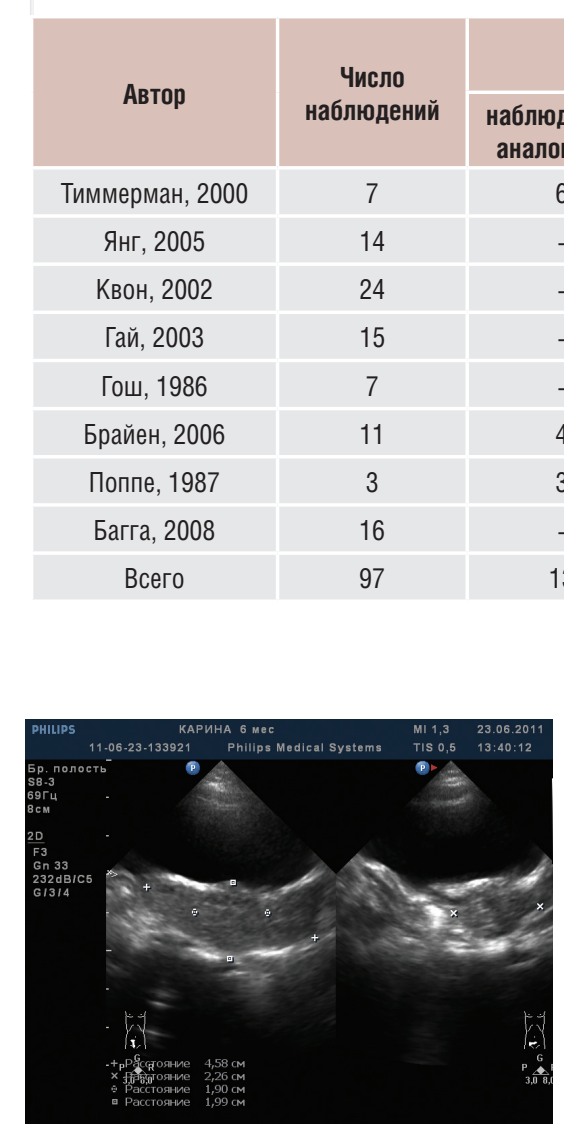

ТАБЛИЦА.

\begin{tabular}{|c|c|c|c|}
\hline \multicolumn{2}{|c|}{$\begin{array}{l}\text { Тактика } \\
\text { лечения }\end{array}$} & \multicolumn{2}{|c|}{ Результат } \\
\hline $\begin{array}{l}\text { дение - } \\
\text { г ГнРГГ }\end{array}$ & ЭМА & ЭМ & беременность \\
\hline
\end{tabular}

\begin{tabular}{|c|c|c|c|}
\hline 6 & 1 & 3 & 0 \\
\hline- & 11 & 4 & 2 \\
\hline- & 22 & 0 & 2 \\
\hline- & 14 & 1 & - \\
\hline- & 6 & 1 & 3 \\
\hline 4 & 11 & - & 5 \\
\hline 3 & 3 & - & 2 \\
\hline- & 13 & 3 & 1 \\
\hline 13 & 81 & 12 & 15 \\
\hline & & & ТАБлицА. \\
\hline
\end{tabular}

МИРОВОЙ ОПЫТ ЛЕЧЕНИЯ ВРОЖДЕННЫХ АВМ МАТКИ (Леваков С.А. и соавт., 2010)
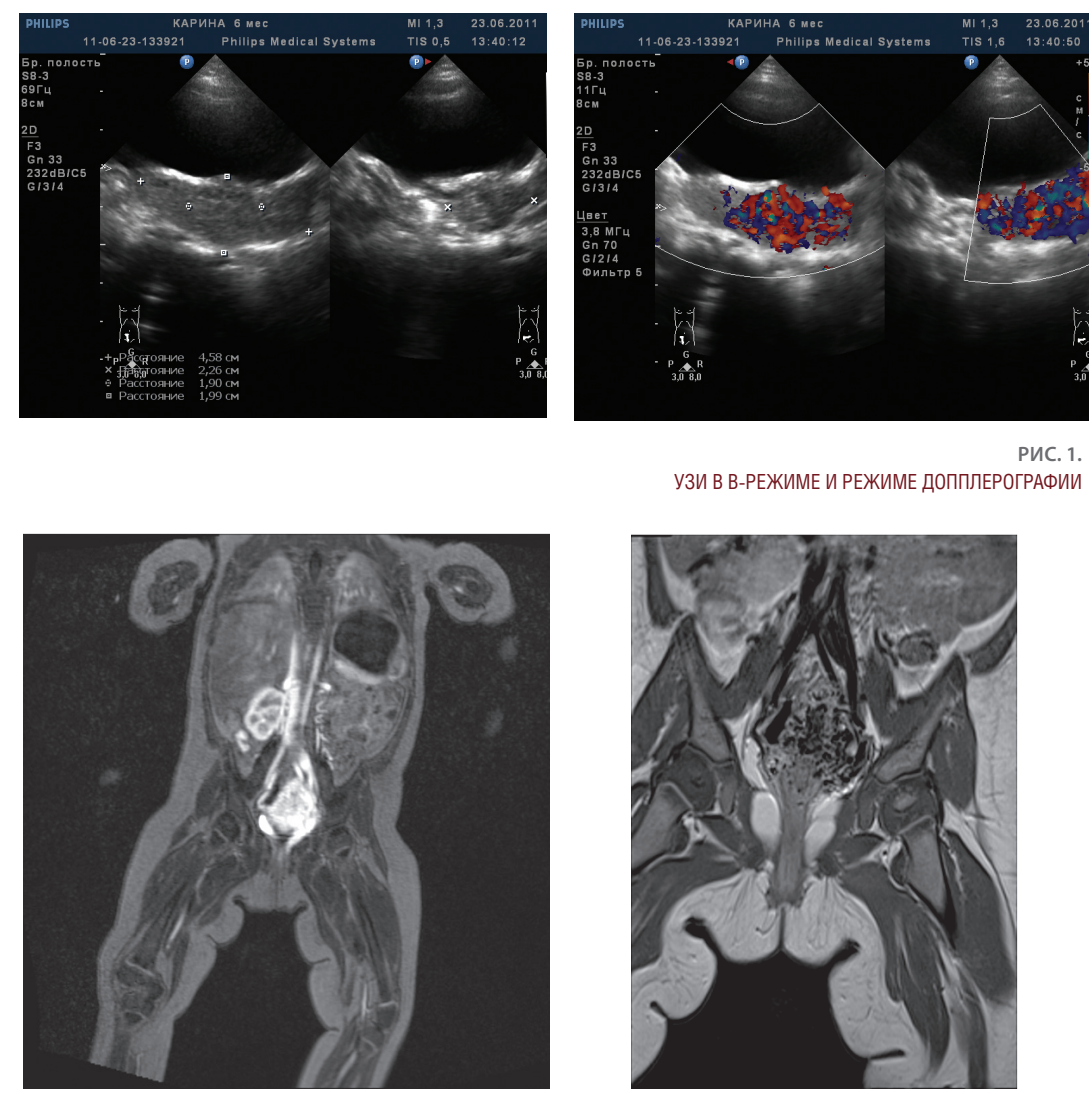

РИС. 1. УЗИ В В-РЕЖИМЕ И РЕЖИМЕ ДОППЛЕРОГРАФИИ

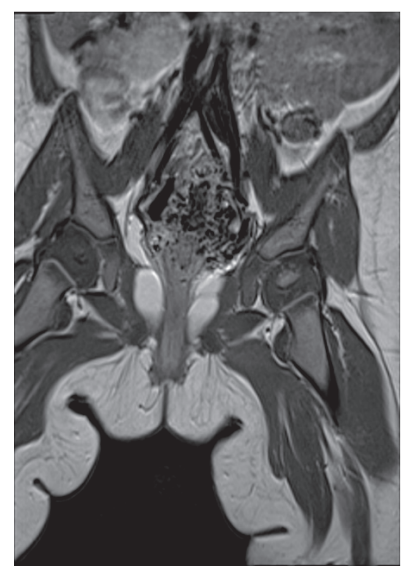

РИС. 2 A. МРТ ДО ЛЕЧЕНИЯ
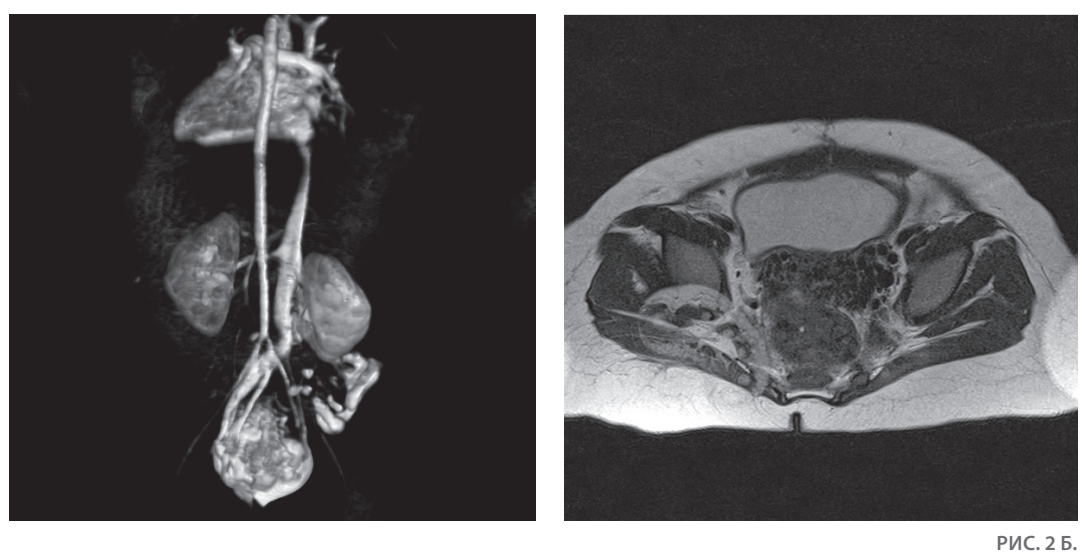

МРТ ДО ЛЕЧЕНИЯ 
25.06.2011 г. девочку консультировал научный сотрудник отдела ангиографии и эндовскулярной хирургии Института хирургии и трансплантологии им. А.А. Шалимова НАМН Украины. Ей поставлен диагноз «врожденная артериовенозная ангиодисплазия сосудов матки». После консультации и обследования запланированы ангиография и эмболизация сосудов.

РИС. 3.

АНГИОГРАФИЯ - ОБЩИЙ ВИД

РИС. 4 (A, Б).

АНГИОГРАФИЯ - ПРАВАЯ МАТОЧНАЯ АРТЕРИЯ ДО (А) И ПОСЛЕ (Б) эМБОЛИЗАЦИИ
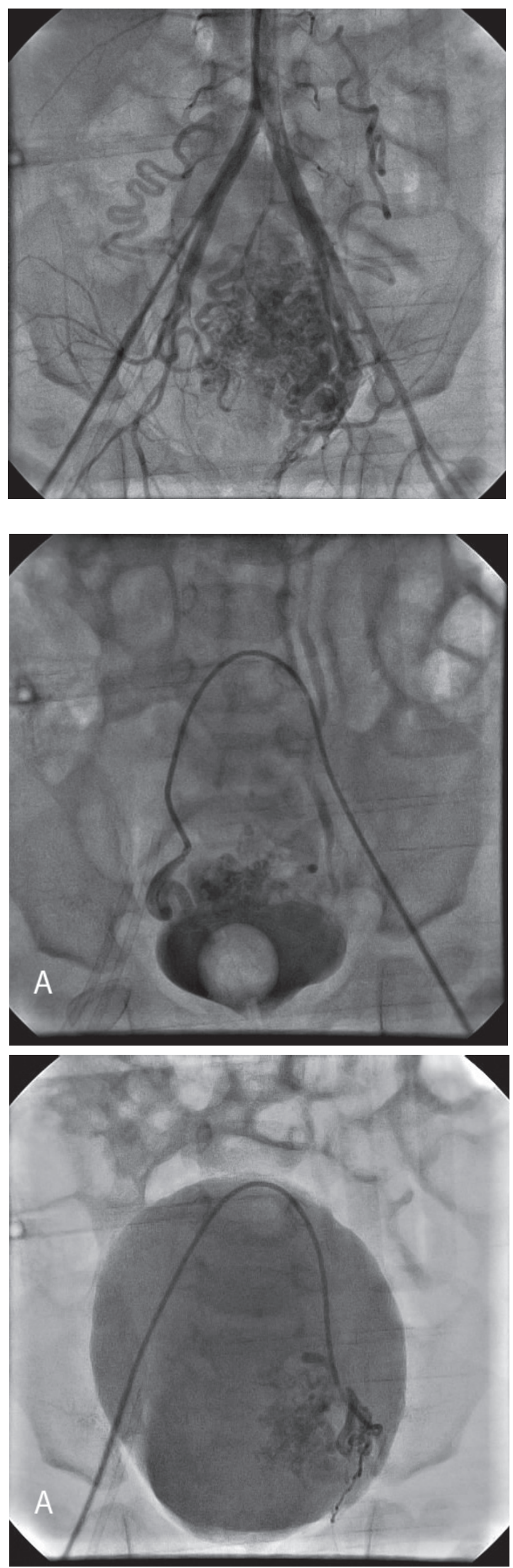

На фроне относительно полного благополучия 1.07.2011 г. появились скудные мажущие кровяные выделения (несмотря на то, что гемостатическая антианемическая терапия проводилась планово), затем - кратковременное обильное кровотечение из половых путей (кровопотеря 160 мл) по типу «открытого и закрытого крана». Это привело к ухудшению состояния ребенка: бледность кожных покровов, кратковременное снижение АД. Девочку перевели в отделение реанимации, где ей были проведены инфузионная терапия, переливание 80 мл свежезамороженной плазмы В (III). Поскольку уровень гемоглобина не снижался до 87 г/л, гемотрансфузию не проводили.

1.07.2011 г. по ургентным показаниям выполнена ангиографрия сосудов малого таза, на которой четко определялось сосудистое образование с высокоскоростным кровотоком, заполняющее значительную часть малого таза - выраженная мальформация, которая васкуляризировалась маточными и яичниковыми артериями с обеих сторон (рис. 3). После селективной ангиографрии была произведена рентгенэндоваскулярная эмболизация правой и левой маточных артерий и левой яичниковой
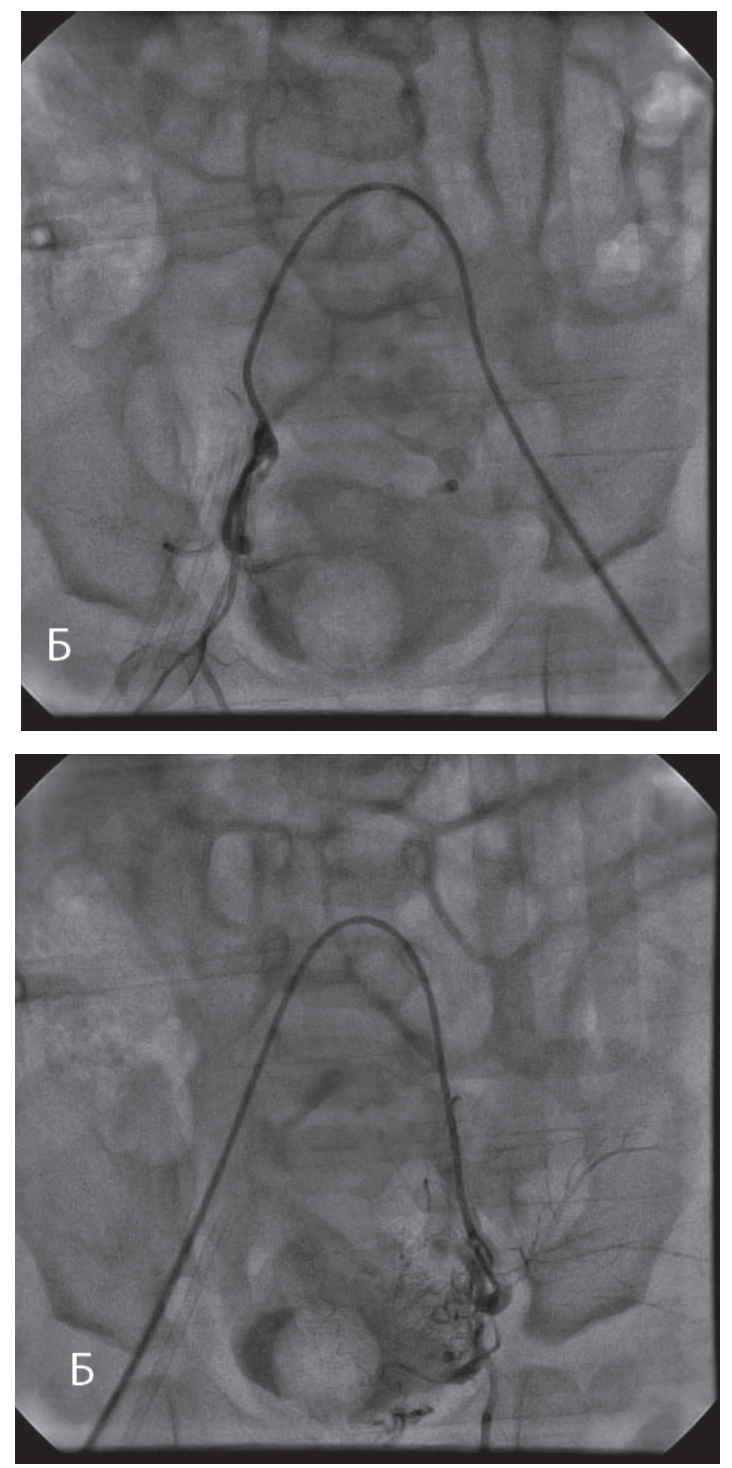
артерии эмболами PVR ø 470 мкр в количестве 100 мг. Правую яичниковую артерию эмболизировать не удалось из-за ее спазма.

При этом выяснилось, что правая маточная артерия значительно расширена, после ее эмболизации отмечено отсутствие кровотока в прилегающем участке, левая маточная артерия имела аналогичные изменения, ее эмболизация также была эффрективна (рис. 4, 5). Наблюдался симптом «стояния контраста».

Операция проведена в центре детской кардиологии и кардиохирургии сотрудниками Центра и Института хирургии и трансплантологии им. А.А. Шалимова.

В ходе операции выполнена гемотрансфузия одногруппной крови. Послеоперационный период протекал гладко, девочка получала антибактериальную и антианемическую терапию.

3.07.2011 г. наблюдались однократно скудные кровянистые выделения около 20 мл.

По данным УЗИ с ЦДК, количество сосудов уменьшилось, скорость кровотока снизилась (рис. 6).

По данным МРТ с внутривенным контрастированием (6.07.2011 г.), отмечена положительная динамика, степень контрастирования образования снизилась, калибр интрамуральных сосудов уменьшился (рис. 7).

Девочка выписана в удовлетворительном состоянии под наблюдение сосудистого хирурга и детского гинеколога по месту жительства. При повторении кровянистых выделений ей рекомендованы повторная ангиография и селективная эмболизация питающих артерий.

\section{ЗАКЛЮЧЕНИЕ}

Анализируя информативность примененных диагностических методов, следует отметить, что УЗИ в В-режиме при этой АВМ матки малоинформативно, так как удалось определить только небольшую часть образования, расположенного непосредственно в толще матки. При допплерографрии характер кровотока в образовании позволил заподозрить АВМ. Однако истинные размеры образования определить не удалось, возможно, из-за того, что у ребенка шести месяцев исследование может быть проведено только трансабдоминально, и добиться хорошего наполнения мочевого пузыря очень проблематично. Только МРТ с контрастированием позволило окончательно установить диагноз.

Ангиография дала наиболее полное представление об ангиоархитектонике образования и васкуляризирующих его сосудах. Самое существенное преимущество метода состоит в том, что он позволяет при необходимости сразу же провести селективную эмболизацию питающих сосудов.
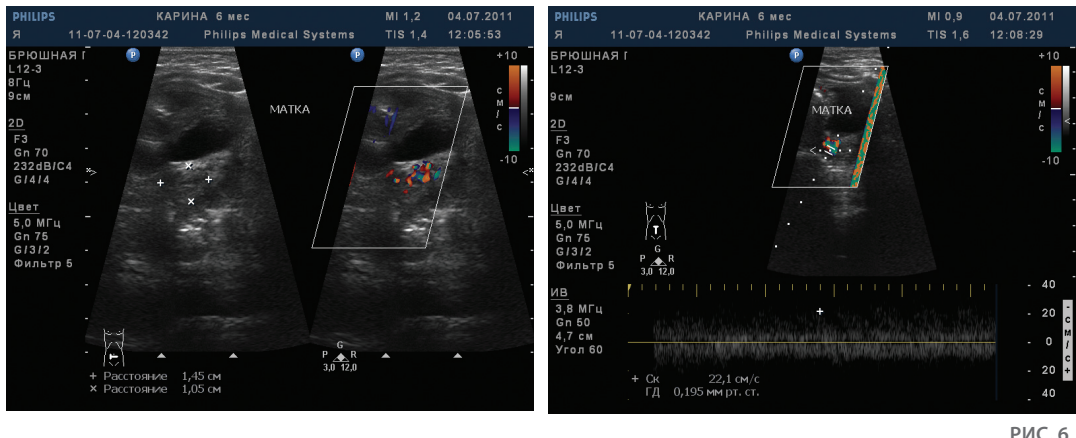

УЗИ ПОСЛЕ ЭМБОЛИЗАЦИИ СОСУДОВ

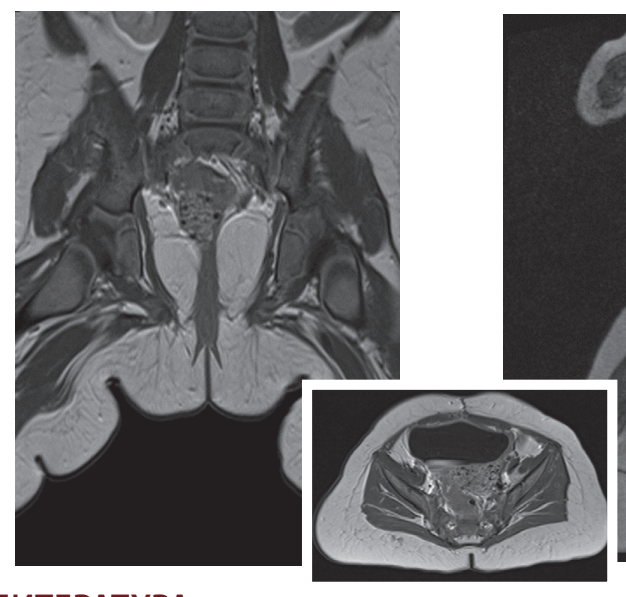

ЛИТЕРАТУРА
1. Допплерография в гинекологии / Под ред. Б.И. Зыкина, М.В. Медведева. - М.:Реальное время, 2000. - 149 с.

2. Леваков С.А., Кедрова А.Г., Нечаева О.Е. и др. Опыт эмболизации маточных артерий при артериовенозной мальформации матки // Клиническая практика. - 2010. № 3. - С. 103 - 111.

3. Сметник В.П., Бугарева Л.Б., Гус А.И., Дан В.Н.

Совершенствование тактики ведения больных с артериовенозной аномалией матки // Проблемы репродукции. 2005. - T. 116. № 2. - C. 66-69.

4. Bagga R., Verma P., Aggarwal N. Faild angiographic embolization in uterine arteriovenous malformations // J. Med. 2008; 10 (1): 12.

5. Ghai S., Raijan D.K. Asch M.R., Muradali et al. Efficacy of embolization in traumatic uterine vascular malformation // J. Vasc. Interv. Radiol. 2003; 14: 1301-1408.

6. Ghosh T.K. Arteriovenous malformation of the uterus and pelvis // Obstet. Gynecol. 1986; 68: 40S-43S.

7. Kasznica J., Nissar N. Congenital vascular malformation of the in stillborn: a case repor // Hum. Patol.- 1995; 26: 2 240-241.

8. Kwon J.H., Kim G.S. Obstetric iatrogenic arterial injuries of the uterus diagnosis with US and treatment with transcatheter arterial embolisation // Radiographics. 2002; 22: 35-46.

9. Laurian C., Leclef Y., Gigou F. et al. Pelvic arteriovenous fistulas: therapeutic strategy in five cases. Ann Vasc Surg 1990; 4 : 1: $1-9$.

10. O'Brien P., Neyastani A., Buckley A.R., Chang S.D., Jegein G.M. Uterine arteriovenous malformation from diagnisis to treatment // Ultrasound Med. 2006; 25:1387-1392.

11. Poppe W., Assche F.A., Wilms G., Favril A., Baert A. Pregnancy after transcateter embolization of uterine arteriovenous malformation // Am.J.Obstet.Gynecol. 1987; 156: 1179-1180.

12. Timmerman D., Van den Boscy T., Peeraer K. et al. Vascular malformation in the uterus; ultrasound diagnosis and concervative management // Eur. J. Obstet. Gynecol. Reprod. Biol. 2000; 92: 171-178.

13. Wautier M.-P., Boval B., Chappey O. et al. Cultured endothelial cells from human arteriovenous malformations have defective growth regulation. Blood 1999; 94; 6: 2020 - 2028.6.

14.Yang J.J., Xiang Y.,.Wan X.P., Yang X.Y. Diagnosis and management of uterine arteriovenous fistulas with massive vaginal bleeding // Int. J. Obstet. Gynecol. 2005; 89: 114-119. 